\title{
Palm Based Mono-Diacylglyceride as an Emulsifier in Producing Chocolate with Cocoa Butter Substitute
}

\author{
Hasrul Abdi Hasibuan ${ }^{1 *}$, Aga Prima Hardika ${ }^{1)}$, and Ijah ${ }^{1)}$ \\ ${ }^{1)}$ Product Processing and Quality Research Group, Indonesian Oil Palm Research Institute, Jl. Brigjen Katamso 51, Medan, Indonesia \\ ${ }^{*}$ Corresponding author: hasibuan_abdi@yahoo.com
}

\begin{abstract}
Emulsifier used in the preparation of chocolate has the function to stabilize fat and water that can prevent the occurrence of blooming. Emulsifier generally used in the preparation of chocolate is lecithin. However as an alternative monodiacylglycerol (MDAG) can be used. MDAG can be synthesized from vegetable oil such as palm oil and its fraction. This research was conducted to study the effect of palm MDAG and variation of its concentration on quality of chocolate. The palm MDAG used was palm kernel oil MDAG (MDAG PKO), palm olein MDAG (MDAG POL), palm stearin MDAG (MDAG PS) at the concentration between 0.3 to $0.9 \%$. Results of the study showed that chocolate which used palm MDAG did not cause blooming. Increase of MDAG concentration tended to increase fat content but the reverse result was observed in the case of lecithin. The melting point of chocolate tended to increase with increasing concentration of MDAG POL and MDAG PS but the reverse result was observed in lecithin, meanwhile for MDAG PKO similar result was observed. The protein content of chocolate tended to decrease with increasing MDAG concentration but the reverse result was observed in lecithin. Viscosity of chocolate with lecithin, MDAG PKO and MDAG POL decreased in accordance with increasing concentration, meanwhile in MDAG PS at the concentration of $0.3 \%$ in the beginning viscosity decreased but later on increased with increasing concentration. The use of emulsifier at the concentration of $0.3-0.9 \%$ did not have significant effect on fat content, melting point of fat and protein content, but it had significant effect on viscosity. Results of organoleptic testing showed that the use of palm MDAG have not significant effect on texture, taste, and appearance of chocolate. Types and concentrations of palm MDAG which were highly accepted by the panelist there were MDAG PS and MDAG PKO with concentration $0.3 \%$ and $0.5 \%$, respectively.
\end{abstract}

Keywords: chocolate, cocoa butter substitute, lecithin, palm oil, palm kernel oil

\section{INTRODUCTION}

Fraction of fat has an important role in the formulation of chocolate since it can determine the texture, appearance, and handling of process and storage of the product. Generally the fat fraction in chocolate is derived from chocolate fat and milk fat (Misnawi \& Wahyudi, 2008). Recently for varying chocolate products and reducing production cost, a part of cocoa fat or even all of the fat is substituted by other kinds of fat consisting of cocoa butter equivalent (CBE) or cocoa butter substitute (CBS) originated from vegetable oil such as palm oil and palm kernel oil. CBE has physicochemical characteristics similar with cocoa fat whereas in CBS only its physical characteristic which 
is similar with cocoa fat (Basiron et al., 2000; Wang et al., 2010; Abdullah \& Zamri, 2011).

The technology of CBS production from palm kernel oil (PKO) can be carried out by fractionation, hydrogenation and its combination. PKO fractionation produces two fractions, i.e. olein and stearin. Stearin fraction is solid with melting point between $30-34^{\circ} \mathrm{C}$ so that it can be applied as CBS. Beside fractionation, hydrogenation of $\mathrm{PKO}$ and its fraction can produce various type of CBS. Completely hydrogenated stearin fraction is CBS with physical characteristic similar to that of cocoa fat with melting point between $33.2-36.8^{\circ} \mathrm{C}$ (Calliauw et al., 2005; Zaidul et al., 2007; Hasibuan et al., 2012; Hasibuan \& Siahaan, 2013).

The obstacle found in the preparation of chocolate with cocoa fat and its mixture with $\mathrm{CBE}$ or CBS is the occurrence of blooming which is shown by existence of white spots on the surface of chocolate. The white spot is fat crystal or diffused sugar (Misnawi \& Wahyudi, 2008; Mulato et al., 2010). One of the efforts to reduce blooming is by adding emulsifier. The emulsifier has the function for reducing surface tension and improve mixing by stabilizing fat and water so that it can influence chocolate characteristic such as blooming, its stability in packing and oxidation (Svanberg et al., 2011). Emulsifier can also make the chocolate more liquid so that it can minimize the use of fat and reduce the production cost (Schantz et al., 2003).

Emulsifier usually used in chocolate product is lecithin originated from yellow egg or soybean (Hartomo \& Widiatmoko, 1993; Pua et al., 2007). Other types of elmulsifier that may be used in the preparation of chocolate is polyglycerol polyricinoleate (PGPR), tri stearate, ammonium phosphatide and mono-diacylglyceride (MDAG) (Schantz
\& Rohm, 2005;Tisoncik, 2010; Graef et al., 2011; Peker et al., 2013).

MDAG is mixture between monoglyceride and diglyceride, both of which have been used as synthetic emulsifier in food industry. Monoglyceride has two free hydroxyl groups, so that its surface activity is stronger than diacylglycerol (Kaewthong \& Kittikun, 2005; Chetpattananondh \& Tongurai, 2008; Hasenhuettl \& Hartel, 2008). MDAG can be prepared from various kinds of oil and fat. Indonesian Oil Palm Research Institute (IOPRI) had prepared various kinds of MDAG using basic material from palm kernel oil, olein and stearine fractions of palm oil. In addition IOPRI had also prepared chocolate with CBS material and lecithin as emulsifier (Hasibuan \& Siahaan, 2012). Therefore this research is conducted to study the use of palm MDAG as emulsifier in the preparation of chocolate with material of CBS that fit with tropical climate.

\section{MATERIALS AND METHODS}

Basic material used in this research were cocoa butter substitute (CBS) and palm mono-diacylglycerol (MDAG) obtained from Research Group of Post Harvest Processing and Quality of IOPRI. CBS was originated from stearin fraction of completely dehydrogenated palm kernel oil, and used as an alternative fat to substitute chocolate fat. CBS contained high lauric acid as much as $56 \%$. Palm MDAG used was originated from palm kernel oil (PKO), palm olein (POL), and palm stearin (PS) with mono-glyceride content of $55-60 \%$ and $30-35 \%$ diglyceride. Cocoa powder was originated from Indonesian Coffee and Cocoa Research Institute (ICCRI) in Jember. Other formulation material was sugar, powder milk, lecithin and vaniline. All materials used were classified as food grade, obtained from a bakery shop in Medan, North Sumatera. 
Chocolate was prepared using standard of IOPRI as presented in Table 1. The materials were mixed and ground in ballmill refiner during 20 hours at the temperature of $50^{\circ} \mathrm{C}$ and then the dough was undergone conching during 10 hours at the temperature of $68^{\circ} \mathrm{C}$ (Sulistyowati \& Misnawi, 2008; Mulato et al., 2010). Afterwards four kinds of emulsifier consisting of MDAG PKO, MDAG POL, MDAG PS and lecithin at concentration of $0.3 ; 0.5 ; 0.7$ and $0.9 \%$ of chocolate weight were added to chocolate product. Addition of emulsifier was done 2 hours before conching finished. Each treatment was replicated twice. The dough was further cooled up to temperature of $35-38^{\circ} \mathrm{C}$, then it was printed and cooled to temperature of $10-12^{\circ} \mathrm{C}$. Chocolate from each treatment was printed in the form of candy with the size of $1 \mathrm{~cm} \times 1 \mathrm{~cm} \times 1 \mathrm{~cm}$. Chocolate was characterized including blooming, fat content, melting point of fat, protein content, viscosity and organoleptic test on taste, texture and appearance of chocolate product. Blooming was determined by detecting the occurrence of white spot layer on the surface of chocolate after cooling and moulding (Bricknell \& Hartel, 1998).

Fat content of chocolate product was determined by extraction using hexan solution in soxhlet apparatus during 8 hours at temperature of $60^{\circ} \mathrm{C}$. Fat was separated from mixture of fat and solution by evaporation. The rest of solution was discarded by further evaporation in the oven at the temperature of $100^{\circ} \mathrm{C}$ during 2 hours. The fat produced was further analyzed its melting point using capillar pipe and cooled at temperature of $0^{\circ} \mathrm{C}$ during 16 hours and determined using standard method (MPOB, 2004).

Composition of fatty acid was determined using gas chromatography apparatus (GC-2010, Shimadzu) by referring to standard method (MPOB, 2004). As much as $0.025 \mathrm{~g}$ sample was added with $1.4 \mathrm{~mL} \mathrm{NaOH}$ methanolic $0.5 \mathrm{~N}$. The mixture was then heated in water boiler at the temperature of $100^{\circ} \mathrm{C}$ during 5 minutes. The mixture was cooled and then $2 \mathrm{~mL} \mathrm{BF}_{3}$ methanol $(14 \% \mathrm{~b} / \mathrm{v})$ was added and heated again at temperature of $100^{\circ} \mathrm{C}$ during 30 minutes. The mixture was cooled and then added with $1 \mathrm{~mL}$ isooctane and stirred during 1-2 minutes. The mixture was added with $5 \mathrm{~mL}$ saturated $\mathrm{NaCl}$ and stirred. Isooctane layer was removed and transferred to the vial, then $1 \mathrm{~mL}$ isooctane was injected to gas chromatography. The column used in the analysis of fatty acid composition was DB-23 J \& W Scientific. Operation condition of gas chromatography was settled at detector and injector temperature of $260^{\circ} \mathrm{C}$. Temperature of oven was programmed in the beginning condition at $70^{\circ} \mathrm{C}$, then increased $20^{\circ} \mathrm{C} /$ minute up to $180^{\circ} \mathrm{C}$, and afterwards it was increased $1{ }^{\circ} \mathrm{C} /$ minute up to $182^{\circ} \mathrm{C}$, then increased $10^{\circ} \mathrm{C} /$ minute up to $220^{\circ} \mathrm{C}$ and maintained during 2 minutes.

Table 1. Cocoa butter substitute based chocolate making recipe

\begin{tabular}{lc}
\hline Ingredient & $\%$ \\
\hline Cocoa butter substitute & 31.0 \\
Cocoa powder & 12.5 \\
Fine sugar & 38.5 \\
Milk powder & 18.0 \\
Vanila & 0.02 \\
Lecithin & In accordance with treatment
\end{tabular}


Protein content of chocolate was determined by Kjeldahl method. Viscosity of chocolate was determined with digital viscosimeter (Brookfield Engineering) using spindle 4 measured at revolving speed of $6 \mathrm{rpm}$ and temperature of $40^{\circ} \mathrm{C}$ (Schumacher et al., 2009).

Organoleptic test was conducted by 25 panelists on chocolate candy based on acceptance test. Panelist was asked to evaluate based on level of preference consisted of taste, texture and appearance. Evaluation of preference used hedonic scale. Score of hedonic scale used for taste, texture and appearance was 5 (very pleased), 4 (pleased), 3 (quite pleased), 2 (less pleased), and 1 (dislike). The data collected was statistically analyzed and followed by Duncan multiple range test for detecting significant difference between treatments.

\section{RESULTS AND DISCUSSION}

Chocolate made in this research used cocoa butter substitute (CBS) as ingredient. CBS had monomorphic stable crystal form ( $b$ and $b^{i}$ ) so that the chocolate product resulted did not require tempering process (Wang et al., 2010). Chocolate dough in this research used cocoa powder containing cocoa fat as much as $20.2 \%$. Cocoa fat was fat which had polymorphic unstable crystal form (Basiron et al., 2000; Sri-Mulato et al., 2010).
Beside containing fat the dough also had moisture content for CBS $(0.03 \%)$, sugar $(1.12 \%)$, milk $(6.78 \%)$, cocoa powder $(3.92 \%)$, lecithin $(0.2 \%)$ and vanilla $(20.8 \%)$. However, moisture in the dough seemed to evaporate during conching process (temperature $68^{\circ} \mathrm{C}$ ). Moisture content in the last product after processing was $0.42 \%$. This value has followed qualification of moisture content in chocolate product, i.e. between $0.4-0.6 \%$. According to Schumacher et al. (2009), the high moisture content in chocolate product caused migration of dough material to the surface of chocolate and resulted in blooming. Meanwhile, chocolate with low moisture content would produce lump that caused the chocolate difficult to melt when it was heated (Afoakwa et al., 2007).

In this research chocolate without addition of emulsifier that did not experience tempering showed white spots on the surface of chocolate with blooming (Table 2). It happened because the fat diffused from the dough and the white spot was CBS fat which was proved by lauric acid content of $55.2 \%$. CBS fat was separated from the dough and did not completely cover cocoa powder particle, sugar, and milk since CBS could not mix perfectly with cocoa fat due to incompatibility between the fat mixed. Basiron et al. (2000) showed that CBS could not perfectly mixed with cocoa powder with a high fat content. Incompatibility between cocoa fat and CBS stimulated the occurrence

Table 2. Effect of emulsifier types and concentration on blooming

\begin{tabular}{|c|c|c|c|c|c|}
\hline \multirow{2}{*}{ Emulsifier } & \multicolumn{5}{|c|}{ Emulsifier concentration } \\
\hline & 0 & $0.3 \%$ & $0.5 \%$ & $0.7 \%$ & $0.9 \%$ \\
\hline Lecithin & blooming & tb & $\mathrm{tb}$ & $\mathrm{tb}$ & $\mathrm{tb}$ \\
\hline MDAG PKO & blooming & tb & tb & tb & tb \\
\hline MDAG POL & blooming & tb & $\mathrm{tb}$ & $\mathrm{tb}$ & $\mathrm{tb}$ \\
\hline MDAG PS & blooming & tb & $\mathrm{tb}$ & $\mathrm{tb}$ & $\mathrm{tb}$ \\
\hline
\end{tabular}


of fat migration (Ghosh et al. 2005; Sabariah et al. cit. Misnawi \& Wahyudi, 2008). According to Bigalli (1988), if two different fat substances were mixed the mixture solidified and melted at lower temperature than the two materials mixed. The use of emulsifier was expected to be able to reduce the surface tension and improved mixing between fat (Misnawi \& Wahyudi, 2008).

Table 2 showed that addition of emulsifier either lecithin or palm MDAG from 0.3 to $0.9 \%$ did not produce white spot without having tempering process. It meant that addition of emulsifier could prevent blooming. Table 2 also showed that addition of emulsifier either lecithin or palm MDAG at $0.3 \%$ could increase compatibility between CBS fat and cocoa fat. Higher concentration of emulsifier caused the surface of chocolate more glossy.

\section{Fat Content}

Determination of fat content was important because it could influence the quality of chocolate produced (Prawira \& Bariinger, 2008). Results of observation of fat content in chocolate product by addition of emulsifier was presented in Table 3. Fat content of chocolate added with palm MDAG tended to increase in accordance with increasing concentration, but the reverse result was observed on lecithin. However increasing concentration of emulsifier did not have significant effect $(p>0.05)$ on fat content because concentration of emulsifier was between $0.3-0.9 \%$.

Fat content of chocolate product increased with increasing concentration of palm MDAG because MDAG was monogly-ceride and diglyceride containing fatty acid. Monoglyceride was fat molecule containing a fatty acid and two hydroxil whereas diglyceride has two kinds of fatty acid and one hydroxil fastened on glycerol (Kaewthong \& Kittikun, 2008; Chetpattananondh \& Tongurai, 2008; Chen et al., 2009). Decrease of fat content with increasing lecithin concentration was caused by low content of phospholipide in lecithin. According to Beuschelberger (2004), Ketaren (2005) and Cabezas et al. (2009), lecithin contained phospholipide, protein, triglyceride, glycolipide, phytosterol, tocopherol, fatty acid and water.

Table 3. Effect of emulsifier types and concentration on chocolate fat content (\%)

\begin{tabular}{lccccc}
\hline \multirow{2}{*}{ Emulsifier } & \multicolumn{5}{c}{ Concentration } \\
\cline { 2 - 6 } & 0 & $0.3 \%$ & $0.5 \%$ & $0.7 \%$ & $0.9^{\%}$ \\
\hline Lecithin & $38.3^{\mathrm{a}} \pm 0,13$ & $38.1^{\mathrm{a}} \pm 0.15$ & $37.9^{\mathrm{a}} \pm 0.12$ & $37.6^{\mathrm{a}} \pm 0.23$ & $36.9^{\mathrm{a}} \pm 0.24$ \\
MDAG PKO & $38.3^{\mathrm{a}} \pm 0,15$ & $38.5^{\mathrm{a}} \pm 0.19$ & $38.6^{\mathrm{a}} \pm 0.28$ & $38.7^{\mathrm{a}} \pm 0.03$ & $39.2^{\mathrm{a}} \pm 0.08$ \\
MDAG POL & $38.3^{\mathrm{a}} \pm 0,20$ & $38.6^{\mathrm{a}} \pm 0.21$ & $39.1^{\mathrm{a}} \pm 0.09$ & $39.6^{\mathrm{a}} \pm 0.15$ & $40.0^{\mathrm{a}} \pm 0.12$ \\
MDAG PS & $38.3^{\mathrm{a}} \pm 0,17$ & $38.4^{\mathrm{a}} \pm 0.20$ & $38.5^{\mathrm{a}} \pm 0.29$ & $38.7^{\mathrm{a}} \pm 0.17$ & $39.5^{\mathrm{a}} \pm 0.11$ \\
\hline
\end{tabular}

Notes: $\quad$ see Table 1 for abbreviation; no significantly different among treatments, $\mathrm{p}>0.05$.

Table 4. Effect of emulsifier types and concentration on chocolate fat melting point $\left({ }^{\circ} \mathrm{C}\right)$

\begin{tabular}{lccccc}
\hline \multirow{2}{*}{ Emulsifier } & \multicolumn{5}{c}{ Concentration } \\
\cline { 2 - 6 } & 0 & $0.3 \%$ & $0.5 \%$ & $0.7 \%$ & $0.9 \%$ \\
\hline Lecithin & $35.0^{\mathrm{a}} \pm 0.05$ & $34.8^{\mathrm{a}} \pm 0.07$ & $34.8^{\mathrm{a}} \pm 0.06$ & $34.6^{\mathrm{a}} \pm 0.04$ & $34.6^{\mathrm{a}} \pm 0.06$ \\
MDAG PKO & $35.0^{\mathrm{a}} \pm 0.07$ & $35.0^{\mathrm{a}} \pm 0.08$ & $35.0^{\mathrm{a}} \pm 0.05$ & $35.0^{\mathrm{a}} \pm 0.03$ & $35.0^{\mathrm{a}} \pm 0.07$ \\
MDAG POL & $35.0^{\mathrm{a}} \pm 0.04$ & $35.0^{\mathrm{a}} \pm 0.10$ & $35.2^{\mathrm{a}} \pm 0.05$ & $35.2^{\mathrm{a}} \pm 0.03$ & $36.0^{\mathrm{a}} \pm 0.06$ \\
MDAG PS & $35.0^{\mathrm{a}} \pm 0.03$ & $35.4^{\mathrm{a}} \pm 0.06$ & $36.0^{\mathrm{a}} \pm 0.05$ & $36.3^{\mathrm{a}} \pm 0.05$ & $36.6^{\mathrm{a}} \pm 0.07$ \\
\hline Notes: see Table 1 for abbreviation; no significantly different among treatments, $\mathrm{p}>0.05$. & &
\end{tabular}




\section{Fat Melting Point}

Misnawi \& Wahyudi (2008) demonstrated that melting point of fat was one of the main factors determining texture and hardness of chocolate candy. The good chocolate did not easily melt at ambient temperature but in the mouth it was melted. Results of measurement of melting point showed that kinds and concentration of emulsifier did not significantly influence ( $p>0.05$ ) on melting point of cocoa fat. Table 4 showed that melting point of cocoa fat increased in accordance with increasing concentration of MDAG POL and MDAG PS, but in MDAG PKO it was relatively the same. Meanwhile melting point of chocolate fat tended to decrease with increasing concentration of lecithin.

Melting point of fat was much influenced by composition of its fatty acid. According to Hasibuan \& Siahaan (2013), CBS from perfectly hydrogenated stearin fraction of palm kernel oil had main component of fatty acid consisted of lauric acid (56.4-61.4\%), miristate (18.6-22.4\%), and palmitate (7.0-8.6\%). Meanwhile, Hasibuan et al. (2012) reported that PKO had composition of main fatty acid lauric acid as much as $48-54 \%$. Therefore the use of MDAG PKO did not change melting point of cocoa fat with CBS material because its characteristic was nearly the same. Results of testing the fatty acid composition showed that MDAG PKO contained fatty acid component especially lauric acid $(47.2 \%)$, miristate $(16.1 \%)$, and palmitate $(9.7 \%)$. MDAG POL had fatty acid component dominated by oleic acid (42.8\%) whereas
MDAG PS was dominated by palmitate acid $(60.5 \%)$.

\section{Protein Content}

Protein content of chocolate added with palm MDAG and lecithin at concentration of $0.3-0.9 \%$ varied between $6.2 \%$ and $6.9 \%$ (Table 5). The higher the palm MDAG concentration the protein content tended to decrease, but the reverse result was observed in the case of lecithin. However increase concentration of emulsifier did not have significant effect $(p>0.05)$ on protein content. Palm MDAG was fat which did not contain protein while lecithin had high protein content which could be used as protein source.

\section{Viscosity}

Viscocity of chocolate added with palm MDAG and lecithin was presented in Figure 1. Type and concentration of palm MDAG and lecithin had significant effect $(p>0.05)$ on viscocity of chocolate. In general, emulsifier used in this research reduced the viscosity of chocolate. Nebesny \& Zyzelewiez (2004) also stated that viscosity of chocolate tended to decrease in accordance with increased amount of emulsifier added. Lecithin could reduce viscosity of chocolate two times higher than that of palm MDAG. The same case had also been mentioned by Schantz et al. (2003), that the use of MDAG was not as good as lecithin because the chocolate produced had higher viscosity and hardness.

Table 5. Effect of emulsifier types and concentration on chocolate protein content (\%)

\begin{tabular}{lccccc}
\hline Emulsifier & \multicolumn{5}{c}{ Concentration } \\
\cline { 2 - 6 } & $0.8^{\mathrm{a}} \pm 0.24$ & $6.9^{\mathrm{a}} \pm 0.14$ & $6.9^{\mathrm{a}} \pm 0.21$ & $7.0^{\mathrm{a}} \pm 0.04$ & $7.1^{\mathrm{a}} \pm 0.14$ \\
Lecithin & $6.8^{\mathrm{a}} \pm 0.26$ & $6.8^{\mathrm{a}} \pm 0.24$ & $6.8^{\mathrm{a}} \pm 0.25$ & $6.5^{\mathrm{a}} \pm 0.14$ & $6.4^{\mathrm{a}} \pm 0.03$ \\
MDAG PKO & $6.8^{\mathrm{a}} \pm 0.34$ & $6.7^{\mathrm{a}} \pm 0.16$ & $6.6^{\mathrm{a}} \pm 0.14$ & $6.6^{\mathrm{a}} \pm 0.20$ & $6.4^{\mathrm{a}} \pm 0.05$ \\
MDAG POL & $6.8^{\mathrm{a}} \pm 0.14$ & $6.8^{\mathrm{a}} \pm 0.22$ & $6.6^{\mathrm{a}} \pm 0.16$ & $6.4^{\mathrm{a}} \pm 0.19$ & $6.2^{\mathrm{a}} \pm 0.18$ \\
MDAG PS & Notes: Table 1 for abbreviation; no significantly different among treatments, $\mathrm{p}>0.05$. &
\end{tabular}




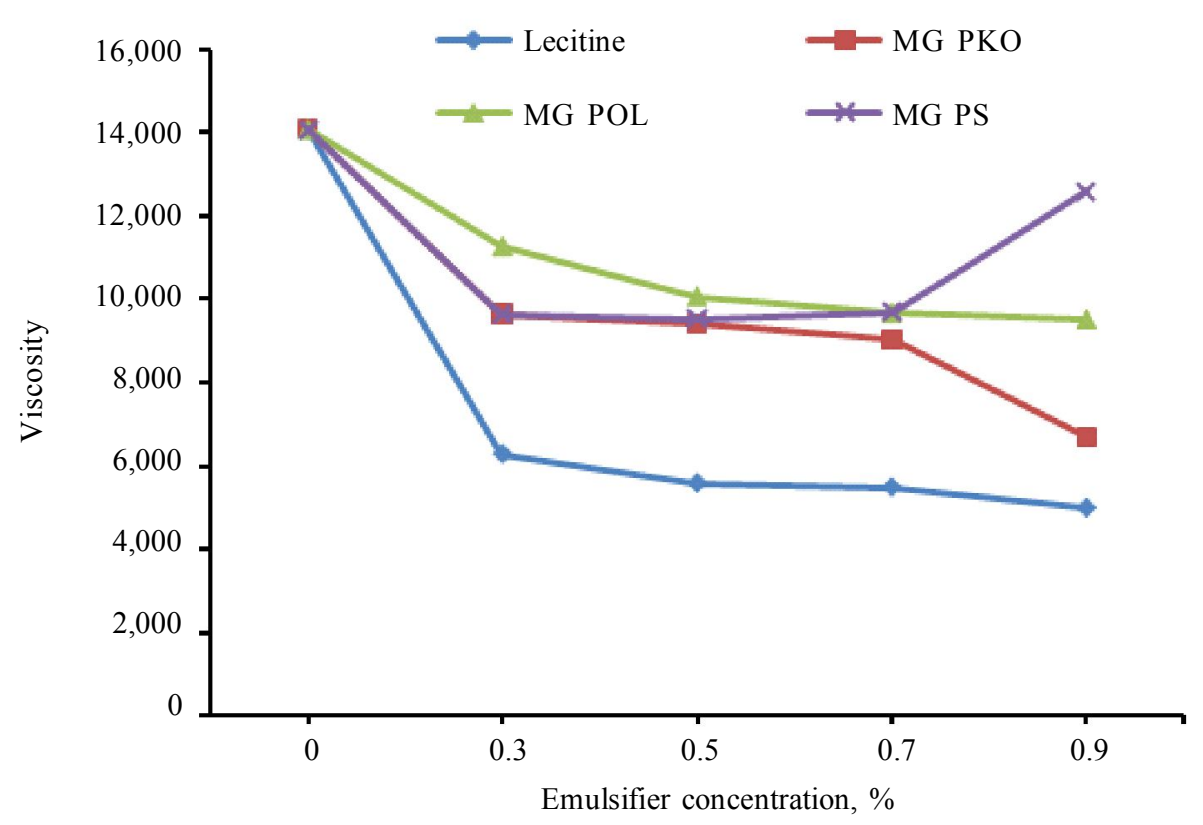

Figure 1. Effect of emulsifier types and concentration on chocolate viscosity

Notes: see Table 1 for abbreviation; no significantly different among treatments, $\mathrm{p}>0.05$.

Lecithin, MDAG PKO and MDAG POL tended to reduce viscosity of chocolate. MDAG PS at concentration of $0.3 \%$ in the beginning reduced viscosity of chocolate but with increasing concentration it tended to increase the viscosity of chocolate. This case was caused by different characteristic of each MDAG emulsifier. In ambient temperature MDAG PKO was fluid whereas MDAG PS was solid. The main material of MDAG had also different shape at ambient temperature. PKO and POL was liquid while PS was solid (Hasibuan \& Siahaan, 2013). Lecithin was also fluid and contained phospholipide and triglyceride with a high oleic acid component of $55-63 \%$ (van Niewenhuysen \& Tomas, 2008).

\section{Organoleptic Test}

Results of organoleptic test of chocolate candy produced by addition of lecithin emulsifier, MDAG PKO, MDAG POL and MDAG PS on taste, texture and appearance was presented in Table 6. Average value of acceptance level varied between 3.42-3.83 which mean that the panelist was nearly like to like. The use of lecithin, MDAG PKO and MDAG POL at the concentration of $0.5 \%$ had relative high level of acceptance, while for MDAG PS was low. Chocolate treated with relative high addition of MDAG PS cause the chocolate become more viscous that it could influence its flavour. According to Hartomo (1993) viscocity of chocolate was one of the important factors and chocolate with high viscocity might become clot when it was consumed. Besides this texture was much influenced by softness of the chocolate product, and according to panelist which used palm MDAG and lecithin it was enough soft. According to Sokmen \& Gunes (2006) particle size above $35 \mu \mathrm{m}$ was felt rough in mouth, but its interval of acceptance was different for each consumer.

Level of acceptance of panelist to chocolate taste was in the position of accepted 
Table 6. Effect of emulsifier types and concentration on preference of chocolate product

\begin{tabular}{lccc}
\hline Emulsifier & Texture & Taste & Appearance \\
\hline No emulsifier & $3.58^{\mathrm{a}} \pm 0.67$ & $2.92^{\mathrm{a}} \pm 0.79$ & $2.42^{\mathrm{a}} \pm 0.79$ \\
Lecithin 0.3\% & $3.50^{\mathrm{a}} \pm 0.58$ & $3.33^{\mathrm{a}} \pm 1.19$ & $3.05^{\mathrm{a}} \pm 0.94$ \\
Lecithin 0.5\% & $3.83^{\mathrm{a}} \pm 0.79$ & $3.33^{\mathrm{a}} \pm 1.16$ & $3.33^{\mathrm{a}} \pm 0.87$ \\
MDAG PKO 0.3\% & $3.58^{\mathrm{a}} \pm 0.72$ & $3.25^{\mathrm{a}} \pm 0.80$ & $3.02^{\mathrm{a}} \pm 0.67$ \\
MDAG PKO 0.5\% & $3.83^{\mathrm{a}} \pm 0.90$ & $3.42^{\mathrm{a}} \pm 1.04$ & $3.25^{\mathrm{a}} \pm 0.90$ \\
MDAG POI 0.3\% & $3.83^{\mathrm{a}} \pm 0.67$ & $2.83^{\mathrm{a}} \pm 0.78$ & $3.17^{\mathrm{a}} \pm 0.75$ \\
MDAG POI 0.5\% & $3.58^{\mathrm{a}} \pm 0.39$ & $3.08^{\mathrm{a}} \pm 0.65$ & $3.25^{\mathrm{a}} \pm 0.65$ \\
MDAG PS 0.3\% & $3.83^{\mathrm{a}} \pm 0.51$ & $3.50^{\mathrm{a}} \pm 0.62$ & $3.50^{\mathrm{a}} \pm 0.79$ \\
MDAG PS 0.5\% & $3.42^{\mathrm{a}} \pm 0.58$ & $3.00^{\mathrm{a}} \pm 0.90$ & $3.08^{\mathrm{a}} \pm 0.87$ \\
\hline
\end{tabular}

Notes: $\quad$ see Table 1 for abbreviation; no significantly different among treatments, $\mathrm{p}>0.05$ ( \pm standard deviation of mean).

except in the case of addition of MDAG POL at $0.3 \%$ and without addition of emulsifier. It was caused by too high viscosity of chocolate without addition of emulsifier and MDAG POL $0.3 \%$ compared to that of other treatments. Panelist acceptance to appearance of chocolate candy was at the level of like except in chocolate without addition of emulsifier. It was proved that without addition of emulsifier the surface of chocolate was not glossy.

Table 6 showed that panelist acceptance to texture, taste, and appearance of chocolate added with lecithin (as a control) was lower than that of palm MDAG. However analysis of variance for texture, taste and appearance of chocolate added with several emulsifier showed not significant difference. This meant that panelist could not differentiate between taste of chocolate which used palm MDAG and that of lecithin.

\section{CONCLUSION}

Palm mono-diacylglyceride (MDAG) could be used as an alternative emulsifier for substituting lecithin in the preparation of chocolate. The use of MDAG did not cause the occurrence of blooming in chocolate product. Kinds and concentration of palm MDAG in the range of $0.3-0.9 \%$ did not have significant effect on parameters tested con- sisting of fat content, melting point of fat, protein content, and organoleptic characteristic of chocolate product except viscosity. Decrease viscosity of chocolate added with MDAG was not as good as that of lecithin. Lecithin could decrease viscosity of chocolate by two times higher compared to that of palm MDAG. From the results of organoleptic test it appeared that kinds and concentration of palm MDAG that could be applied in the preparation of chocolate were MDAG PKO and PS at concentration of $0.5 \%$ and $0.3 \%$, respectively.

\section{REFFERENCES}

Abdullah, M.S. \& A.I. Zamri (2011). Cocoa butter substitute of chocolate by using corn starch/xanthan gum/glycerin blends and their effects on melting, rheological and nutritional properties. Empowering Science, Technology and Innovation Towards a Better Tomorrow, 26, 339-343.

Afoakwa, A.O.; A. Paterson \& M. Fowler (2007). Factors influencing rheological and textural qualities in chocolate - a review. Trends in Food Science Technology, 18, 290-298.

Basiron, Y.; B.S. Jalani \& C.K. Weng (2000). Advances Oil Palm Research. Volume II, Malaysian Palm Oil Board, Malaysia.

Bigalli, G.L. (1988). Practical aspects of the eutectic effect on confectionery fats 
and their mixtures. The Manufactures and Confectionery, 68, 65-80.

Bricknell, J. \& R.W. Hartel (1998). Relation of fat bloom in chocolate to polymorphic transition of cocoa butter. Journal of American Oil Chenists Society, 75, 1609-1615.

Bueschelberger, H.G. (2004). Lecithins: In Emulsifiers in Food Technology. R.J. Whitehurst (Ed.), Wiley-Blackwell.

Cabezas, D.M.; B.W.K. Diehl \& M.C. Tomas (2009). Sunflower lecithin: application of a fractionation process with absolute ethanol. Journal of American Oil Chemists' Society, 86, 189-196.

Calliauw, G.; I. Foubert; W.D. Greyt \& P. Dijckmans (2005). Production of cocoa butter substitute via two-stage fractionation of palm kernel oil. Journal of American Oil Chemists Society, 82, 783-790.

Chen, C.H.; I. van Dammeb \& E.M. Terentjev (2009). Phase behavior of $\mathrm{C} 18$ monoglyceride in hydrophobic solutions. The Royal Society of Chemistry, Soft Matter, 5, 432-439.

Chetpattananondh, P. \& C. Tongurai (2008). Synthesis of high purity monoglicerides from crude glycerol and palm stearin. Songklanakarin Journal of Science and Technology, 30, 515-521.

Graef, V.D.; F. Depypere; M. Minnaert \& K. Dewettinck (2011). Chocolate yield stress as measured by oscillatory rheology. Food Research International, 44, 2660-2665.

Ghosh, V.; G.R. Ziegler \& R.C. Anantheswaran (2005). Moisture migration through chocolate-flavored confectionery coatings. Journal of Food Engineering, 66, 177-186.

Hartomo, A.J. \& M.C. Widiatmoko (1993). Emulsi dan Pangan Instant Berlesitin. Andi Offset, Yogyakarta.

Hasenhuettl, G.L. \& R.W. Hartel (2008). Food emulsifiers and their applications. Springer Science + Business Media . pp. 11-37.
Hasibuan, H.A.; D. Siahaan; M. Rivani \& F. Panjaitan (2009). Minyak sawit dan minyak inti sawit sebagai bahan baku formulasi plastic fat dan specialty fat. pp. 295-304. Prosiding Pertemuan Teknis Kelapa Sawit.

Hasibuan, H.A. \& D. Siahaan (2012). Pengaruh waktu conching terhadap mutu produk cokelat berbahan cocoa butter substitute. Jurnal Penelitian Kelapa Sawit, 20, 33-41.

Hasibuan, H.A.; D. Siahaan \& Sunarya (2012). Kajian karakteristik minyak inti sawit Indonesia dan produk fraksinya terkait dengan amandemen standar Codex. Jurnal Standardisasi, 14, 98-104.

Hasibuan, H.A. \& D. Siahaan (2013). Karakteristik CPO, Minyak Sawit dan Fraksinya. Buku Saku Seri 31, Pusat Penelitian Kelapa Sawit, Medan.

Kaewthong, W. \& A.H. Kittikun (2005). Continous production of monoglycerols by glycerolysis of palm olein with immobilized lipase. Journal of Process Biochemistry, 40, 1525-1530.

Ketaren, S. (2005). Minyak dan Lemak Pangan. UI Press, Jakarta.

Misnawi \& T. Wahyudi (2008). Pengaruh konsentrasi stearin dan lesitin terhadap sifat fisik permen cokelat. Pelita Perkebunan, 24, 49-61.

MPOB (2004). MPOB Test Method: A Compendium of Test on Palm Oil Products, Palm Kernel Products, Fatty Acids, Food Related Products and Others. Malaysian Palm Oil Board, Malaysia.

Nebesny, D.E. \& D. Zyzelewiez (2004). Effect of lecithin concentration on properties of sucrose-free chocolate masses sweetened with isomalt. European Food Research Technology, 220, 131-135.

Peker, B.B.; S. Sunai; C.E. Tamer \& O.U. Copur (2013). The effects of lecithin and polyglycerol polyricinoleate (PGPR) on quality of milk, bitter and white 
chocolates. Journal of Agricultural Faculty of Uludag University, 27, 55-69.

Prawira, M. \& S.A. Barringer (2008). Effects of conching time and ingredients on preference of milk chocolate. Journal of Food Processing and Preservation, 33, 571-589.

Pua, C.K.; A. Sheikh; N. Hamid; G. Rusul \& A. Rahman (2007). Production of drum-dried jackfruit (Artocarpus heterophyllus) powder with different concentration of soy lecithin and gum arabic. Journal of Food Engineering, $78,630-636$.

Schantz, B. \& H. Rohm (2005). Influence of lecithin-PGPR on the rheological properties of chocolate. LWT-Food Science Technology, 38, 41-45.

Schantz, B.; L. Linke \& H. Rohm (2003). Effect of different emulsifiers on rhelogical and physical of chocolate. $3^{\text {rd }}$ International Symposium on Food Rheology and Structure.

Schumacher, A.B.; A. Brandelli; E.W. Schumacher; F.C. Macedo; L. Pieta; T.V. Klug \& E.V. De Jong (2009). Development and evaluation of a laboratory scale conch for chocolate production. International Journal of Food Science and Technology, 44, 616-622.

Sokmen, A. \& G. Gunes (2006). Influence of some bulk sweeteners on rheological properties of chocolate. LWT-Food Science and Technology, 39, 1053-1058.

Sri-Mulato; S. Widyotomo; Misnawi \& E. Suharyanto (2010). Pengolahan Produk Primer dan Sekunder Kakao. Pusat Penelitian Kopi dan Kakao, Jember, Jawa Timur.
Sulistyowati \& Misnawi (2008). Effects of alkali concentration and conching temperature on antioxidant activity and physical properties of chocolate. International Food Research Journal, 15, 1-8.

Svanberg, L.; L. Ahrne; N. Loren \& E. Winadhab (2011). Effect of sugar, cocoa particles and lecithin on cocoa butter crystallisation in seeded and non-seeded chocolate systems. Journal of Food Engineering, 104, 70-80.

Tisoncik, M.A. (2010). Impact of Emulsifiers on Physical, Sensory, and Microstructural Properties in Formulated Dark Chocolate with an Innovative Educational Approach. Master Thesis. University of Illinois, Urbana-Champaign.

van Nieuwenhuyzen, W. \& M.C. Tomas (2008). Update on vegetable lecithin and phospholipid technologies. European Journal of Lipid Science and Technology, 110, 472-486.

Wang, F.; Y. Liu; L. Shan; Q. Jin; X. Wang \& L. Li (2010). Blooming in cocoa butter substitute based compound chocolate: investigation on composition, morphology and melting behaviour. Journal of the American Oil Chemists' Society, 87, 1137-1143.

Zaidul, I.S.M.; N.A.N. Norulaini; A.K.M. Omar \& R.L. Smith (2007). Blending of supercritical carbon dioxide $\left(\mathrm{SC}-\mathrm{CO}_{2}\right)$ extracted palm kernel oil fractions and palm oil to obatine cocoa butter replacers. Journal of Food Engineering, 78, 1397-1409.

$$
* * 0 * *
$$

